\title{
Analysis of Off Highway Truck Caterpillar 773E General Overhaul (GOH) Interval
}

\author{
Muhammad Ruspinuji ${ }^{1}$, and Nani Kurniati ${ }^{2}$
}

\begin{abstract}
PT XYZ is a heavy equipment rental company and mining contractor. One of its working areas is an open coal mine in South Kalimantan, obtained a contract to lease heavy equipment in the form of 14 (fourteen) Caterpillar 773E Off Highway Trucks. Mine owner have availability targets and application of penalties, $P T$ XYZ must implement appropriate maintenance and maintenance strategies. In 2018, the OHT total down time is 34,061.30 hours. For 15,272.00 hours (44.8\%) downtime is caused by major component breakdown. The high cost of repairing components makes it difficult for company management to determine the decision to repair. To meet the heavy equipment availability target of mine owner, PT $X Y Z$ must implement appropriate maintenance and maintenance strategies. High off Highway Truck (OHT) availability can be achieved by minimizing downtime. The purpose of this research is to determine a general overhaul (GOH) time interval that has the greatest effect on the availability of Caterpillar 773E Off Highway Truck. In order for minimization of downtime to have a significant impact, it must be determined which critical components have the most influence on costs. Next step is determined the GOH interval by considering the smallest cost impact. The results of research show Caterpillar 773E OHT critical components are engine, transmission, final drive and torque converter. The $\mathrm{GOH}$ interval is 17,992.81 hours.
\end{abstract}

Keywords-Availability, Heavy Equipment, Off Highway Truck, General Overhaul, Interval, Critical Component.

\section{INTRODUCTION}

PT XYZ is a heavy equipment rents company, received a lease contract with a mining company in South Kalimantan. The customer's target of availability is $85 \%$ and gets a penalty if it does not meet the target. One type of equipment for rent is the Caterpillar 773E off highway truck (OHT) with totalling 14 (fourteen) units. The population is $73.6 \%$ of total fleet. During 2018, the total down time for the off highway truck was $34,061.30$ hours. For $15,272.00$ hours $(44.8 \%)$ downtime is caused by major component breakdown. The cost of major component repairs has made it difficult for the company management to determine the decision to repair, considering that the general overhaul costs were very high.

This research will determine when the general overhaul schedule on the Caterpillar 773E off highway truck so that

${ }^{1}$ Muhammad Ruspinuji is with Department of Business Management, Institut Teknologi Sepuluh Nopember, Indonesia. Email: ruspinuji@gmail.com.

${ }^{2}$ Nani Kurniati is with Department of Industrial Engineering, Institut Teknologi Sepuluh Nopember, Indonesia. Email: nanikur@gmail.com. it can obtain effective and efficient replacement intervals in terms of time so that it can increase the availability of these equipment which will increase the satisfaction and trust of the customer. By knowing the general overhaul time interval, a scheduling simulation can be arranged.

\section{LITERATURE REVIEW}

\section{A. Project Management}

Project management is science, capability, facilities and techniques / methods in project activities in order to meet stakeholder needs and expectations of a project with completion through the implementation of initiating, planning (planning), executing, monitoring and controlling, closing by balancing the demands of competing projects on the scope, quality, schedule, budget, resources, risk [1]. In contrast to the definition with Project Management Institute, H. Kerzner [2] that project management is planning, organizing, leading, and controlling company resources to achieve predetermined short-term goals.

\section{B. Project Planning}

Planning is a process that tries to lay the foundations of goals and objectives and prepare all the resources to achieve them. Planning provides a handle for the implementation of the allocation of resources to carry out activities [2]. Broadly speaking, planning functions to lay the basis of the project's objectives, namely scheduling, budgeting and quality.

According to [3], in project management, determining the time to complete this activity is one of the most important initial activities in the planning process because determining the time will be the basis for other plans, namely:

a. Scheduling, budgeting, human resource needs (man power planning), and other organizational resources.

b. Control process (controlling). Project Management includes three phases [4], namely:

1. Planning. This phase includes setting goals, defining the project, and the organization of the team.

2. Scheduling. This phase connects people, money, and materials for specific activities and connects each activity to one another.

3. Control. The company oversees resources, costs, quality, and budget. The company also revised or changed plans and shifted or re-managed resources to meet the time and cost needs. 


\section{Maintenance}

Maintenance has been around since humans built physical assets such as houses, boats and agricultural equipment. Equipment that is used continuously will experience a decrease in its ability. There are two types of equipment decline, namely:

1) Natural Deterioration, which is a decrease in the performance of the engine or equipment naturally due to deterioration / wear on the physical machine / equipment during the time of use even though the use is correct.

2) Accelerated deterrence, namely the decline in the performance of a machine or equipment due to human error so that it can accelerate the wear of machinery or equipment because it is caused by improper action or treatment of the equipment.

The maintenance approach can basically be divided into two parts, namely Planned and Unplanned Maintenance. The care system approach classification is:

a. Planned Maintenance, an act of maintenance that is organized and carried out with thoughts into the future, control and recording in accordance with a predetermined plan. Therefore, the maintenance program that will be carried out requires active supervision and control.

b. Unplanned Maintenance, an act of care or maintenance whose implementation time is not planned in advance. Unplanned maintenance usually takes the form of breakdown / emergency maintenance.

\section{Mean Time To Failure (MTTF)}

MTTF is the average time between failures or the average operating time of a component or system without failing. MTTF is a comparison between operating time and number of failures in a certain time period.

$$
\begin{aligned}
& \text { MTTF }=\frac{\text { operation Time }}{\text { Number of Breakdown }} \\
& \text { MTTF }=\eta \Gamma\left(\frac{1}{\beta}+1\right)
\end{aligned}
$$

The MTTF time unit in this research is the hour.

\section{E. Pareto}

$\mathrm{ABC}$ analysis or known as Pareto classification is one method that is used to solve the problem of determining the optimum point, both the number of orders and order points, and is useful in determining the items that must be prioritized. Based on $\mathrm{ABC}$ analysis $10 \%$ of goods contribute to $70 \%$ of the value and is called group A, group B represents $20 \%$ of goods that contribute to $10 \%$ of the value. This shows that by controlling a small portion of goods, which is $10 \%$ of the total amount of goods, it will result in control of $70 \%$ of total inventory[5]. Besides ABC classification follows the 80-20 principle or Pareto law, where about $80 \%$ of the total material inventory value represents $20 \%$ of material inventory.

\section{F. Previous research}

Research on the maintenance interval analysis has been carried out by several previous researchers with different methods as well. The result of implementing previous research will be a comparison and reference in conducting this research. Summary of the research that has been done along with the research methods that related to the topic of maintenance can be seen on Table 1 .

\section{Methodology}

This research will optimize general overhaul time intervals. The first step is to collect list of GOH OHT 773E components and overhaul cost. Critical components are determined using the $\mathrm{ABC}$ pareto / analysis method based on overhaul cost. Second step is determining the characteristics of the failure data. Third step is determining the characteristics of maintenance data. Fourth Step is calculated the cost of component life loss hours and corrective replacement costs. Final Step is calculated of impact cost refer to MTTF of each component. The Research flowchart shows on the Figure 1.

TABLE 1.

\begin{tabular}{|c|c|c|c|c|}
\hline No & Year & Author & Title & Method \\
\hline 1 & 2008 & Baradaby, Javad [6] & $\begin{array}{l}\text { Reliability Analysis of Mining Equipment : A Case Study of Crushing Plant at Jajarm } \\
\text { Bauxite Mine in Iran }\end{array}$ & $\begin{array}{l}\text { ReliabilityBased } \\
\text { Time Interval }\end{array}$ \\
\hline 2 & 2012 & Satria, Yhatna [7] & $\begin{array}{l}\text { Analysis of Determining Time Intervals for Critical Component Replacement in QCS } \\
\text { Scanner Type 2200-2 Instrument Tool at PT Tjiwi Kimia Paper Factory }\end{array}$ & $\begin{array}{l}\text { ReliabilityBased } \\
\text { Time Interval }\end{array}$ \\
\hline 3 & 2013 & $\begin{array}{l}\text { Putra, Trisian Hendra } \\
{[8]}\end{array}$ & $\begin{array}{l}\text { Determination of Time Interval for Sub-Sub System Replacement on Heidelberg CD } \\
102 \text { Machine at PT X }\end{array}$ & $\begin{array}{l}\text { ReliabilityBased } \\
\text { Time Interval }\end{array}$ \\
\hline 4 & 2016 & $\begin{array}{l}\text { Febrianti, } \\
\text { Winy [9] }\end{array}$ & $\begin{array}{l}\text { Determination of Preventive Maintenance Time Intervals in Urea Unit Synthesis Unit } \\
\text { Equipment at PT. X uses Monte Carlo Simulation. }\end{array}$ & $\begin{array}{l}\text { Monte } \\
\text { Simulation }\end{array}$ \\
\hline 5 & 2015 & Arpurtaraj, M. E [10] & Studies On Availability And Utilization Of Mining Equipment - An Overview & Study overview \\
\hline
\end{tabular}

PREVIOUS RESEARCH 


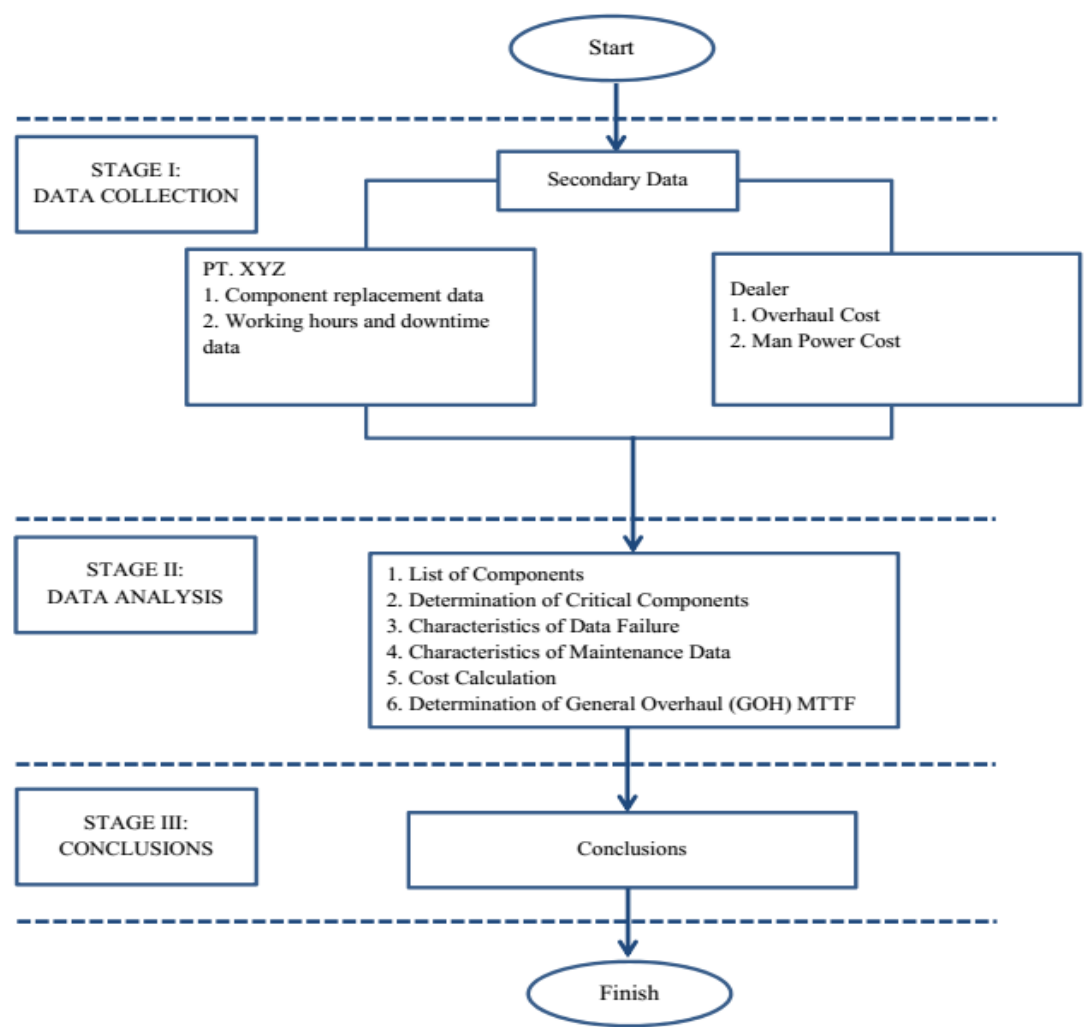

Figure 1. Research Flow Chart.

\section{RESUlT AND DISCUSSION}

This research will optimize general overhaul time intervals. The first step is to collect list of GOH OHT 773E components, then critical components are determined using the ABC pareto / analysis method based on overhaul cost. Second step is determining the characteristics of the failure data. Third step is determining the characteristics of maintenance data. Fourth Step is calculated the cost of component life loss hours and corrective replacement costs. Final Step is calculated of impact cost refer to MTTF of each component.

\section{A. List Component and Determination Critical Components of the 773E Off Highway Truck}

Major component data and the amount of overhaul costs per each component are presented in Table 2. Based on the Table 2, then pareto analysis is implemented by using Minitab 16 software. The results can be seen on the Picture 2. From Picture 2, five critical components are determined, and then the critical component is further analyzed.

\section{B. List Component and Determination Critical Components of the 773E Off Highway Truck}

The next step is collecting time data between replacing the five components, and distributing using the Weibull ++ 6 program. The result of data distribution shows in Table 3. MTTF is obtained by calculating the parameters of table 3 with equation 2 . The results show in Table 4.
TABLE 2.

MAJOR COMPONENT LIST AND OVERHAUL COST

\begin{tabular}{|c|c|}
\hline Component & Cost (in millions) \\
\hline Engine & Rp 1,378 \\
\hline Transmission & Rp 470 \\
\hline Final Drive R/H & $\mathrm{Rp} \quad 241$ \\
\hline Final Drive L/H & $\mathrm{Rp} \quad 241$ \\
\hline Torque Conventer & $\mathrm{Rp} \quad 161$ \\
\hline Differential & $\mathrm{Rp} \quad 86$ \\
\hline Front Wheel R/H & $\mathrm{Rp} \quad 67$ \\
\hline Front Wheel L/H & $\mathrm{Rp} \quad 67$ \\
\hline Rear Axle & $\mathrm{Rp} \quad 37$ \\
\hline Suspension-Rear R/H & $\mathrm{Rp} \quad 40$ \\
\hline Suspension-Rear L/H & $\mathrm{Rp} 40$ \\
\hline Radiator & Rp 34 \\
\hline Suspension-Front $\mathrm{R} / \mathrm{H}$ & Rp 34 \\
\hline Suspension-Front L/H & $\mathrm{Rp} 34$ \\
\hline Cyl-Hoist R/H & $\mathrm{Rp} 25$ \\
\hline Cyl-Hoist L/H & Rp 25 \\
\hline Cyl-Steering R/H & Rp 24 \\
\hline Cyl-Steering L/H & Rp 24 \\
\hline Fan Drive & $\mathrm{Rp} 17$ \\
\hline
\end{tabular}


The $1^{\text {st }}$ International Conference on Business and Management of Technology (IConBMT)

August 3rd 2019, Institut Teknologi Sepuluh Nopember, Surabaya, Indonesia

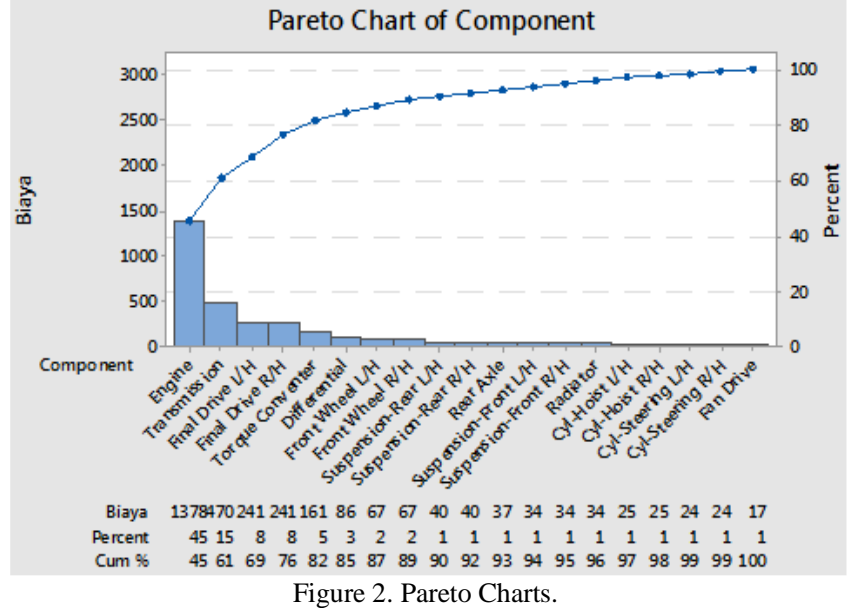

TABLE 3.

DISTRIBUTION DATA AND PARAMETER OF CRITICAL COMPONENT

\begin{tabular}{cccc}
\hline \hline \multirow{2}{*}{ Component } & \multicolumn{3}{c}{ Time To Failure (TTF) } \\
\cline { 2 - 4 } & Distribution & Parameter & Value \\
\hline Engine & Weibull 2 & Beta $(\beta)$ & 3.7056 \\
& & $\operatorname{Eta}(\eta)$ & 19936 \\
\hline Transmission & Weibull 3 & $\operatorname{Beta}(\beta)$ & 4.2358 \\
& & $\operatorname{Eta}(\eta)$ & 23425 \\
\hline Final Drive & Weibull 2 & $\operatorname{Beta}(\beta)$ & 3.6133 \\
& & $\operatorname{Eta}(\eta)$ & 24563 \\
\hline Torque Conventer & Weibull 2 & $\operatorname{Beta}(\beta)$ & 2.9746 \\
& & $\operatorname{Eta}(\eta)$ & 24199 \\
\hline \hline
\end{tabular}

TABLE 4

MTTF OF CRITICAL COMPONENT

\begin{tabular}{llcc}
\hline \hline \multirow{2}{*}{ Component } & \multicolumn{3}{c}{ Time To Failure } \\
\cline { 2 - 4 } & Parameter & Value & MTTF \\
\hline Engine & Beta $(\beta)$ & 3.7056 & 17992.81 \\
& Eta $(\eta)$ & 19936 & \\
\hline Transmission & Beta $(\beta)$ & 4.2358 & 21302.28 \\
& Eta $(\eta)$ & 23425 & \\
\hline Final Drive & Beta $(\beta)$ & 3.6133 & 22138.28 \\
& Eta $(\eta)$ & 24563 & \\
\hline Torque Conventer & Beta $(\beta)$ & 2.9746 & 21601.19 \\
& Eta $(\eta)$ & 24199 & \\
\hline \hline
\end{tabular}

TABLE 5 .

HOURLY COMPONENT VALUE

\begin{tabular}{ccccc}
\hline \hline No & Component & Component Value & MTTF & $\begin{array}{c}\text { Hourly Component } \\
\text { Value }\end{array}$ \\
\hline 1 & Engine & $\operatorname{Rp~1,364,746,660}$ & 17992.81 & $\operatorname{Rp~75,850}$ \\
2 & Transmission & $\operatorname{Rp~468,105,633~}$ & 21302.28 & $\operatorname{Rp~21,974~}$ \\
3 & Final Drive & $\operatorname{Rp~238,320,720~}$ & 22138.28 & $\operatorname{Rp~10,765~}$ \\
4 & $\begin{array}{c}\text { Torque } \\
\text { Converter }\end{array}$ & $\operatorname{Rp~158,664,482}$ & 21601.19 & $\operatorname{Rp~7,345}$ \\
\hline \hline
\end{tabular}

TABLE 6.

HOURLY COMPONENT VALUE

\begin{tabular}{clc}
\hline \hline No & Component & Additional Cost \\
\hline 1 & Engine & $\operatorname{Rp~} 816,990,900$ \\
2 & Transmission & $\operatorname{Rp~304,840,483~}$ \\
3 & Final Drive $R H$ & $\operatorname{Rp~339,511,075~}$ \\
4 & Final Drive $L H$ & $\operatorname{Rp~339,511,075~}$ \\
5 & Torque Converter & $\operatorname{Rp~300,439,814~}$ \\
\hline \hline
\end{tabular}

\section{Cost Calculation}

To calculate the MTTF GOH is by simulation, taking into account two cost factors, namely the cost of component life loss hours and corrective replacement additional costs.

\section{1) Cost of Loss Component Hours Life.}

The component values obtained from the overhaul costs refer to table 2 and MTTF values from table 4.

$$
\text { Hourly component values }=\frac{\text { Component Value }}{M T T F}
$$

Component values obtained from overhaul costs refer to the table 2 . The following table 5 hourly component values for critical components

\section{2) Additional Cost for Corrective Replacement}

Corrective replacement surcharge is the additional cost of damage caused by a corrective. These costs are obtained from the history that has occurred with the current price from the dealer presented in table 6 .

\section{MTTF of $\mathrm{GOH}$}

$\mathrm{GOH}$ impact cost calculation will be calculated by referring to the MTTF of each component (table 4). By calculating the hour's life loss component and corrective replacement surcharge, $\mathrm{GOH}$ cost impact is obtained. $\mathrm{GOH}$ MTTF is determined by MTTF components which have the lowest $\mathrm{GOH}$ impact. With the following steps:

1) Determine the reference components, in this case can take one of the critical components with the MTTF reference that show in Table 4.

2) Calculating loss component hour's life. Perform MTTF difference calculation between the reference component and other components (MTTF reference component minus other components), whether negative or positive. The difference is positive if the MTTF reference component is greater than the other component MTTF, and vice versa. Then the value is multiplied by the value of the hourly component based on table 5 .

3) Additional corrective replacement costs are included in the calculation if the reference MTTF is greater than the other component MMTF. Can be seen in the calculation results in table 6 .

4) Then the second step minus the third step, it was caused the additional cost of corrective replacement is always negative.

5) Simulation is carried out with reference to each component. Then the results are added up. 
The $1^{\text {st }}$ International Conference on Business and Management of Technology (IConBMT)

August 3rd 2019, Institut Teknologi Sepuluh Nopember, Surabaya, Indonesia

The results are presented in table 7 . Based on the Table 7, the engine has lowest GOH impact, and then the MTTF GOH is the MTTF Engine, which is 17,992.81 hours.

TABLE 7 GOH IMPACT COSTS WITH REFERENCE TO EACH COMPONENT

\begin{tabular}{clccr}
\hline \hline No & Component Reference & MTTF & \multicolumn{2}{c}{ Impact Cost } \\
\hline 1 & Engine & $17,992.81$ & $-\mathrm{Rp}$ & $188,480,688.57$ \\
2 & Transmission & $21,302.28$ & $-\mathrm{Rp}$ & $1,565,625,819.80$ \\
3 & Final Drive $R H$ & $22,138.28$ & $-\mathrm{Rp}$ & $480,243,189.37$ \\
4 & Final Drive LH & $22,138.28$ & $-\mathrm{Rp}$ & $480,243,189.37$ \\
5 & Torque Converter & $21,601.19$ & $-\mathrm{Rp}$ & $318,195,609.08$ \\
\hline \hline
\end{tabular}

\section{CONCLUSION}

The critical component of the 773E off highway at PT X is determined by a pareto analysis which consider the overhaul cost. Five critical components along with the value of the overhaul cost are engine, transmission, final drive and torque converter.

$\mathrm{GOH}$ cost impact refers to each component from the lowest to the highest are engine (-Rp 188,480,689), torque converter (-Rp 318,195,609), final drive LH (-Rp 480,243,189), final drive LH (-Rp 480,243,189), transmission (-Rp. 1,565,625,820). Refer to results engine was chosen as a reference for MTTF GOH of 17,992.81 hours.

\section{REFERENCES}

[1] PMI (Project Management Institute), "PMBOK Guide 5th Edition," 2013.

[2] I. Soeharto, Manajemen Proyek dari Konseptual Sampai Operasional. Jakarta: Penerbit Erlangga, 2012.

[3] S. Siswanto, Operation Research. Jakarta: Erlangga, 2007.

[4] J. Heizer and B. Render, Operation Management, 7th ed. New Jersey: Prentice Hal, Inc, 2005.

[5] H. K. Atmaja, "Penggunaan Analisis ABC Indeks Kritis untuk Pengendaliaan Persediaan Obat Antibiotik di Rumah Sakit M. H. Thamrin Salemba," Universitas Indonesia, 2012.

[6] J. Barabady and U. Kumar, "Reliability analysis of mining equipment: A case study of a crushing plant at Jajarm Bauxite Mine in Iran," Reliab. Eng. Syst. Saf., vol. 93, no. 4, pp. 647653, Apr. 2008.

[7] Y. Satria, "Analisa Penentuan Interval Waktu Penggantian Komponen Kritis pada Alat Instumentasi QSC Scanner Type 2200-2 di PT Pabrik Kertas Tjiwi Kimia,” Institut Teknologi Sepuluh Nopember, 2012.

[8] T. H. Putra, "Penentuan Interval Waktu Penggantian Sub-Sub System pada Mesin Heidelberg CD 102 di PT X," Institut Teknologi Sepuluh Nopember, 2013.

[9] W. Febrianti, "Penentuan Interval Waktu Perawatan Pencegahan pada Peralatan Sub Unit Sintesa Unit Urea di PT. X menggunakan Simulasi Monte Carlo," Institut Teknologi Sepuluh Nopember, 2016.

[10] M. E. M. Arputharaj, "Studies on Availability and Utilisation of Mining Equipmente - An Overview," Int. J. Adv. Res. Eng. Technol., 2015. 